\title{
Kahoot in Maritime English Teaching: Its Impact on Nautical Science Cadet's Oral Reproduction and Vocabulary
}

\author{
Sri Sartini \\ Nautical Science of Sekolah Tinggi Maritim Yogyakarta, Indonesia \\ sartinisri69@gmail.com
}

\begin{abstract}
This type of research was Participatory Action Research using the Denzin and Lincoln (2005) model which consists of the Kahoot pre-action cycle and post-action cycle. This study aimed to examine the use of Kahoot Platform in Maritime English learning. It improved the speaking skill of nautical science cadets by the increasing number of maritime vocabularies as an indication. The results of this study described that the use of Kahoot quiz made learning experienced in the classroom very interactive, interesting, and effective, because of the two cycles carried out increased from the beginning of the cycle to the next cycle marked by the increasing number of correct answers done by the cadets. Thus, their vocabulary mastery increased as well. Kahoot not only increased vocabularies that supported cadet's speaking skill initiated by the correct oral reproduction, but also increased cadet's enthusiasm in learning Maritime English. In conclusion, the use of online gamification-based Kahoot quiz toward nautical science cadets at Sekolah Tinggi Maritim Yogyakarta had a significant impact on vocabulary mastery for effective communication skills.
\end{abstract}

Keywords: Kahoot quiz, maritime English, oral reproduction

How to Cite: Sartini, S. (2020). Kahoot in maritime English teaching: Its impact on nautical science cadet's oral reproduction and vocabulary. English Language Teaching Educational Journal, 3(1), 41-51

\section{INTRODUCTION}

Digital technology-based learning in the 4.0 era has become a compulsory that cannot be negotiated. In fact, the era of the industrial revolution was not only in the economic field but also in the field of Education. This is in line with the statement of Saturno, Pertel, Deschamps, and de F.R.Loures E. (2018) that entering this era, education must adopt the current knowledge by involving technological sophistication such as the use of Artificial Intelligence (AI), Cloud, Big Data, IoT, and Robotic. Stanic, Hadjina, Fafandjel, and Matulja (2018) also mention that in fact, industrial revolution 4.0 transformations have spread into maritime sector and shipbuilding industry. Therefore, a variety of careful preparation needs to be done for the success of learning in any sector. Those forms of learning preparation are preparing materials as well as the assessment procedure to measure the ability of students to understand the information and material provided. Besides determining the media to be used in learning is also important. Educators become an important key in the learning preparation process. With those good learning preparations by educators, it is hoped that the quality and learning targets will be well- achieved according to the expected result and it leads to qualified and benefited outcomes.

Maritime English Learning in maritime higher education is mandatory and it is crucial. It is mentioned by Pratama and Sartini (2019) that in era of industrial revolution 4.0, maritime higher education must produce qualified human resources that should be wellacknowledged with the technology and proficient in English. Maritime English learning includes English for specific purposes. English teaching which belongs to specific purposes is important (Hutchinson \& waters, 1987) and it requires practical teaching which combines the theories and practice (Nunan, 2003). The International Maritime Organization (IMO) as a global maritime policy regulator has issued a Nautical Science cadets handbooks of IMO Model course 7.03 that is for deck officers and IMO Model Course 7.04 for prospective 
engine room officers. Those handbooks both regulate curriculum content that must be given to prospective seafarer officers to meet minimum requirements as professional, competent and skillful seafarers so that the graduates or cadets are ready with the market needs at national and international levels. In fact, English which is considered as a foreign language in Indonesia is a big challenge in the Maritime teaching process. This is due to the fact that learning a foreign language is not that easy. As it is argued by Nunan (1999), the measurement of successful foreign language teaching is the student's capability of making conversation in the targeted language. Further Farabi, Hassanvand, and Gorjian (2017) also claim that capability in speaking shows proficient skill in the targeted language. Meanwhile, the targeted Indonesian seafarers needed are those who are capable and skillful in mastering knowledge in their fields and able to communicate actively in minimally English as one of international languages. Another statement from Florez (1999) says that speaking should be prioritized in language learning. More active language skills are demonstrated by the ability to speak up or give utterances. On the other hand, as it is mentioned by St-Pierre and Beland (2010) the word reproduction means to, good speaking skill can be derived from the ability of making correct oral reproductio state the production of language both in written and orally. Therefore, speaking skills initiated by correct oral reproduction become more emphasized skills for all prospective seafarers including the Nautical Science cadets. Effective teaching strategies to enhance cadet speaking skills through oral reproduction and vocabulary drills are also very important.

Various language teaching methods are now available. E-learning method by involving Gamification (game-based learning) becomes one of positive alternatives to improve the achievement of learning objectives. This is due to the fact that E-learning with gamification provides attractive learning opportunities and is not boring. Esteve, Pereira, Veiga, and Vasco (2018) state that GBL (gamification-based learning) can make learning interactive, interesting and effective. He considers that game-based learning makes the learner get motivation that encourages the learner to get new knowledge easily according to his learning experience. Haryanto (2018) highlights that E-learning model as a game-based learning creates faster and easier transfer of knowledge. The term Game-based learning emerged from Cheng, C. H. and Su, C.H (2012) who tried to compare conventional or traditional learning methods with game-based learning methods and found that game-based methods provide more learning. Wiggins (2016) also states that gamification-based learning provides an alternative teaching and learning process that is new. Further explained that the existing facilities in E-learning can connect the distance (between educators and cadets) separated by space and time. In E-Learning method educators and cadets can be connected to online classes even if they are in separate place. In addition, besides it attracts the enthusiasm of cadets in learning it can also support the learning process itself becoming easier, more practical, and even preparing human resources who are ready with technology.

One of the E-learning lessons that can be done is the use of Kahoot. Kahoot Media is a learning media based on online gamification that can utilize the features as a quiz, questionnaire, survey and others. Kahoot was created by three talented entrepreneurs namely Johan Brand, Jamie Brooker, and Morten Versvik in 2013 (Vidhiasi, 2018). By Kahoot game, educators can provide various types of quizzes, tests, questions that are designed to measure the ability of cadet's knowledge according to the material which is already transferred. Learning becomes interesting because all cadets using gadgets or cell phones can be directly involved actively in learning with other cadets and with educators. Indirectly Kahoot makes learning integrated with the use of technology and provides space 
for cadets to explore more with technology. Kahoot quiz was used by researchers to improve cadets' vocabularies mastery in order to achieve effective speaking skills by a lot of drills. This is inseparable from the statement that vocabulary knowledge is one of important elements in supporting one's speaking skill. By the increased mastery of vocabulary knowledge cadets will also immerge on their oral reproduction because every vocabulary given has its phonetic symbol. Using Kahoot, the lecturer involved the quiz to assess the cadet's knowledge on phonetic transcription upon certain word. Thus it leads cadets to produce correct sound on every word tested. From this analysis it is known that it is true if learning which involves E-learning or online-based media in the form of game is needed by cadets. Therefore, the researcher examined the use of Kahoot as an alternative effort to improve speaking skills initiated by oral reproduction of the cadets of Sekolah Tinggi Maritim Yogyakarta. It begins with the formation of vocabulary mastery so that learning difficulties in English especially in the field of speaking skills both in general and Maritime English context which has been difficult may find a solution. As it is mentioned by the previous research conducted by Vidhiasi (2018), learning by Kahoot game instead of learning with old-fashioned method makes them communicate more each other, being more attracted and the Kahoot method enhance teaching and learning process. Eventhough, he focused his study on the use of Kahoot to teach standard marine communication phrases, it showed similarity that it was related to student's speaking skill.

Further, Hadijah, Pratolo, and Rondiyah confirm that Kahoot (2020) can help the students to be more active and it provides fun learning in the classroom, and makes the students more enthusiastic in doing the test. However, their research also found some negative sides of using Kahoot. First, the students become less confident especially when they get lower scores than other students; second, some students had a lack of knowledge in using the application; and the last, the time was limited. Furthermore, Esteves et.al (2018) strengthens that Kahoot is one of the tools to get the students being involved well in learning process besides there are other tools like EDpuzzle and socrative. The previous researchers tried to prove the effectiveness of Kahoot to teach standard maritime communication phrases (SMCP) and to teach any materials as a whole, here the researcher burden of proof was how the use of Kahoot might influence and had impact on cadet's speaking skill through the effective design of vocabulary and oral reproduction drills or tests.

\section{RESEARCH METHOD}

This research included participatory action research Denzin and Lincoln (2005) by involving researchers directly involved in the research process from the beginning to the end of the process. In this classroom action research data were collected through tests, observations, questionnaire, and documentation. In maritime English teaching, there was a standardized English used to converse among seafarers which was issued by International Maritime Organization. Therefore, this standard was used by the researcher as valid basis of the test and evaluation given in every cycle of quiz. The research method used was a combination method (mixed method) of sequential exploratory type that the data obtained were analyzed descriptive qualitatively then strengthened quantitatively in the form of a percentage obtained with IBM SPSS Statistics 23. There were two cycles of Kahoot usage, Pre-action Kahoot intended to identify the use of Kahoot as a vocabulary drills in order to support the cadets' oral reproduction skills in the evaluation of early learning. The postaction Kahoot was used to find out the improvement in learning outcomes using the quiz. Each cycle contained stages of planning, acting, observing, and reflecting or using Kemmis and Taggard model (1988) as explained in Arikunto (2015). Planning in the pre-action Kahoot was done by making a learning scenario about wheel order, casting off procedure, 
and internal communication on bridge. Besides scenario, making observation sheet and designing evaluation materials through Kahoot quiz were done. Acting stage was done by implementing Kahoot as a teaching media. Once acting stage was done, observation was then conducted to ensure how the quiz ran. Afterward reflection was noted in order to note down the weaknesses and the strengths to be evaluated ahead in the next cycle. Therefore, the weaknesses could be eliminated and the strengths could be maintained. By the increasing score in the use of Kahoot, vocabulary mastery and oral reproduction skills of cadets were assumed to increase. This was due to the same subject area which were used in the quiz. Those as research subjects were cadets of the Nautical Science program in 2018/2019 with total numbers of 21 people.

Table 1. The Blueprint of the Kahoot Test

\begin{tabular}{lll}
\hline No. & \multicolumn{1}{c}{ Section } & Number \\
\hline 1. & Wheel order & 5 \\
2. & Casting off procedure & 5 \\
3. & Internal communication on bridge & 5 \\
\hline
\end{tabular}

\section{FINDINGS AND DISCUSSION}

\section{Pre-action Kahoot}

Kahoot quiz was given in two cycles namely Kahoot pre-action and post-action Kahoot. Each quiz on each cycle contains vocabulary knowledge related to the use of Maritime English both for internal and external communication on board. For pre-action activities, some materials were given related to internal communication on board such as Maritime English that is used in conducting communications on the bridge between watchkeeping officers (for example steering orders or wheel orders, use of international alphabet, order of casting off ropes to officers on the deck both the front deck (bow) and the rear deck (stern) when the ship will do berthing and unberthing procedures and when the ship will do anchoring. In addition to the material also alluded to parts of the vessel in four times meetings, cadets were given the material above and Kahoot quiz was given as evaluation material. This information had been well-informed in advance so that cadets understood well that they had to get well-prepared for the exam with the Kahoot quiz. cadets studied more actively to prepare for the quiz. This was because they felt a little embarrassed if they could not answer the question. Each material was given in the form of a role play conversation as well as vocabulary drills according to their respective topics.

The researcher observed the learning experiences of the cadets in doing role play and understanding the vocabulary used in the contents of the conversation. It was found during the role play that some cadets were still less active because in each group there must be cadets who might be more dominating so that other cadets tend to be passive. There were also less active cadets because they were still not confident in communicating in English. On the other hand, it was also found that some cadets already understood the concept of the standard Marine communication phrases (SMCP) delivered, but in this cycle they still felt insecure about their English pronunciation or articulation. As a follow up, the lecturer gave a Kahoot quiz as an effort to strengthen vocabulary mastery and strengthen their articulation. Here it was the difference from the previous research lies in. Previous research done by Vidhiasi (2018) proved how Kahoot could be used to teach standard maritime communication phrase. Whereas Esteves et.al (2018) proved the use of fun Kahoot in learning process instead of other fun online game. However, here researcher proved how 
Kahoot could bring impact on vocabulary mastery and oral reproduction of cadets which later contribute to cadets' speaking skill. It was found by using the quiz, it turned out that cadets learn more actively and responsibly because each of them used their gadgets and participated totally without external coercion. This game-based quiz turned out to have a strong motivational effect on the cadets so that they were more serious about working on the quiz without even being asked by their own active lecturer. It seems that learning was more fun for them and the questions in the form of vocabulary memorization tests and articulation of sounds that are right for them were not a burden unlike other written tests that might be felt draining their energy and mind further it sounds monotonous.

One of the highlights of this quiz to be used as a media of learning and evaluation is that this quiz was limited by the time for each question and answer displayed so that the cadets must really focus and concentrate on the questions that did not appear on their gadget screens but only appear on the lecturer slide screen. After a few moments the questions were closed automatically and the answer choices given within a few seconds were set according to the lecturer decision. Here it was where the excitement of this game lies in because they had to use the right vocabulary and chose the right words for the right expressions in English especially according to the material given. The results of the Kahoot pre-action quiz were as shown below.

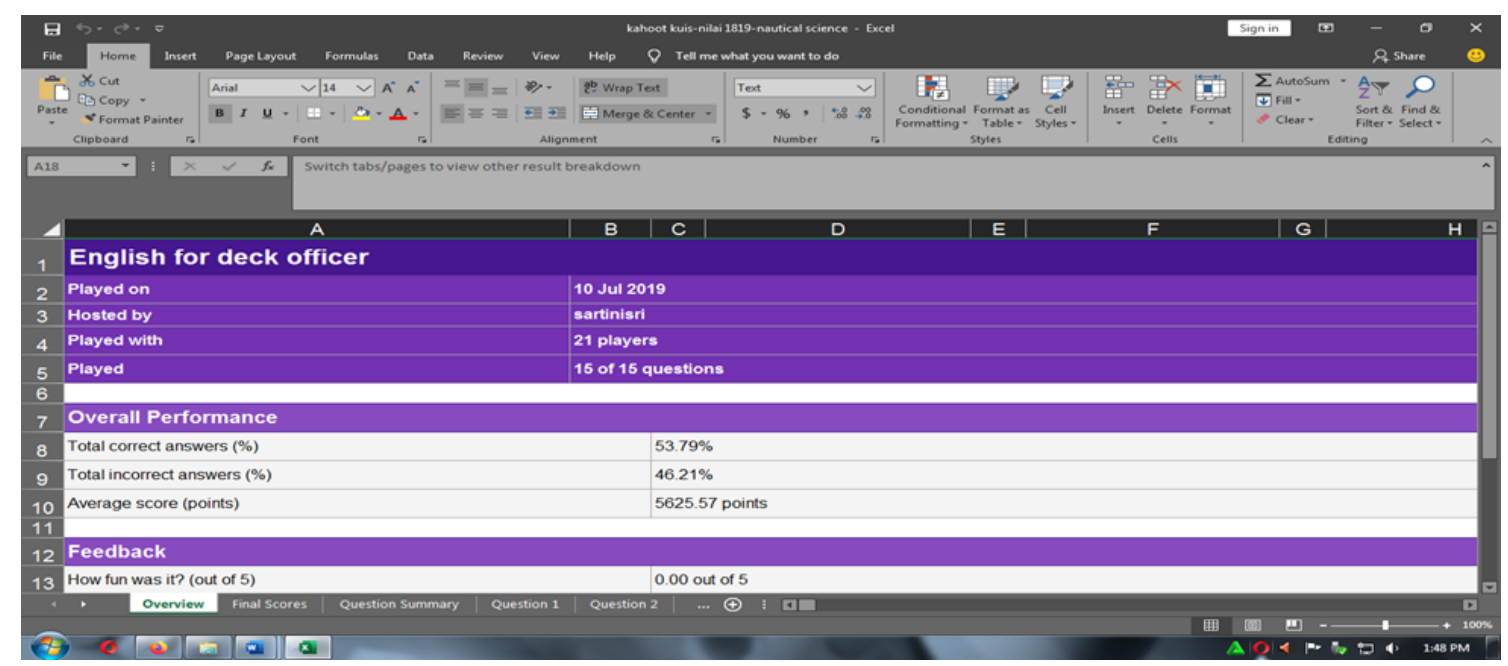

Figure 1. Percentage Form of Pre-Action Kahoot Score

From the figure, it is known that from 21 Nautical science cadets, the total correct answer is $53.79 \%$ while the total incorrect answer is $46.21 \%$. Some errors that often occurred are questions related to standard wheel orders and internal communication on bridge. For example, when cadets were asked a question to say the "right 15 degree" steering command according to the SMCP they should choose the "starboard fifteen" but many of them chose the "fifteen starboard" even though the phrase already has its own standard. From the observation done, it was found that the cadets who answered correctly but they were considered to be wrong by the system were due to the time laps to think and answer questions over because it was just 10 seconds length. While for cadets who answered incorrectly, there were indeed many of them who experienced panic situation between having to think quickly to find answers by only being given a very limited time. So the level of their panic became the main factor causing them to fail in answering correctly. However, those who did the Kahoot quiz seemed to be enthusiastic and very happy regardless of the results of their answers. They felt motivated and enthusiastic. The results of the Kahoot pre-action quiz can be analyzed as follows. 
Tabel 2a. Pre-Action Kahoot

\begin{tabular}{lrr}
\hline \multicolumn{2}{c}{ Statistics of Kahoot Result } \\
\hline $\mathrm{N}$ & Valid & 21 \\
& Missing & 0 \\
Mean & & 7.4762 \\
Std. Deviation & & 1.50396 \\
Minimum & & 5 \\
Maximum & & 10 \\
\hline
\end{tabular}

Tabel 2b. Pre Kahoot

\begin{tabular}{rrrrrr}
\hline & Frequency & Percent & Valid Percent & Cumulative Percent \\
\hline Valid & 5.00 & 2 & 9.5 & 9.5 & 9.5 \\
& 6.00 & 4 & 19.0 & 19.0 & 28.6 \\
& 7.00 & 4 & 19.0 & 19.0 & 47.6 \\
& 7.00 & 33.3 & 33.3 & 81.0 \\
& 7.00 & 1 & 4.8 & 4.8 & 85.7 \\
& 3 & 14.3 & 14.3 & 100.0 \\
& 10.00 & 21 & 100.0 & 100.0 & \\
& Total & & & &
\end{tabular}

From the statistics above it is known that all cadets worked by answering a total of 15 questions. The maximum number of questions that can be answered correctly is 10 questions. The average question that can be answered correctly by cadets is eight questions.

Table 3. Pre Kahoot Analysis

\begin{tabular}{ccl}
\hline No. & \multicolumn{1}{c}{ Section } & Percentage \\
\hline 1. & Wheel order & 9.5 \\
& Steering order & \\
2. & Casting off procedure & 23.5 \\
& Procedure single up line and spring & \\
& Procedure heave up line and spring & \\
& Procedure let go all rope & 20.79 \\
3. & Internal communication on bridge & \\
& Ensuring Course and speed \\
& Duties of watchkeeping on bridge \\
\hline
\end{tabular}

From the table above it is also known that out of 53,79\% correct answer of the cadet's trial frequently correct answer were on the material of "Casting off procedure". It means that cadet understood well the material about procedure of letting go all rope and line or spring better than the other two material sections of wheel order and internal communication on bridge. This fact was well noted as a reflection or a highlight of the lecturer to prioritize in the next cycle of Kahoot quiz.

Based on the observation done during the quiz which was written down in observation sheet, it was found that some of the failures in answering questions by the 21 cadets were caused by the panic situation. It correlates to the questionnaire distributed showing that this quiz was their first time to deal with. However, based on the observation sheet 16 cadets out of 21 or it is about $76,19 \%$ they became more enthusiastic about 
memorizing the vocabulary taught and managing their own level of panic. Fortunately, this motivation would be benefit for them for the next cycle of Kahoot.

\section{Post-action Kahoot}

Kahoot's post action quiz was given to evaluate vocabulary mastery related to external communication on board which involved internal communication as the basis terms to send information. External communication included ship to ship communication, ship to Vessel traffic services (VTS) communication and ship to shore communication. However, the communication used still well-related to the internal communication therefore the vocabulary used were also related. External communication which was tested in Kahoot covered the same expressions which were applied for internal communication. For example, in external communication ship to ship, "standard wheel orders" which belong to internal communication used in the first cycle Kahoot were used in term of sending message to tell about the current position and present course of the ship. This communication was intended to avoid the collision of the vessels. Another example of external communication which used internal communication basis was ship to shore communication such as the activity when the vessel intended to do berthing in a port. Before the vessel moored to the quay, it had to send a "casting off procedure" or sending out rope to the port labors. Besides, internal communication on bridge was also important to send external communication especially between ship to VTS. For instance when the vessel starts to enter or leave a port, it had to give information to VTS as well as asking permission to pass the fairway. External communication involved the terms used for internal communication on board. However the dialogue and vocabularies used based on researcher's observation were more difficult to memorize than that of internal communication. Hence, it could be stated if the result of next cycle quiz using Kahoot is better than the previous means that the Kahoot itself was effective to conduct. The distinguish of the pre and post Kahoot lied in the length of the utterances and vocabularies tested. Both tested the use of the same basic internal communication which were applied as a means of internal communication on board and external communication on board. Learning from experiences in the previous cycle, cadets did not want to fail again in answering questions in the next cycle of Kahoot quiz. Based on observation sheet, their obstruction in the first cycle was due to the lack of vocabulary mastery in Maritime English context. Then they became very motivated to memorize those vocabularies and terminologies. Expecting by mastering the vocabulary according to the topic of the exam, they would be no longer panic in working on the quiz. And his confidence grew up.

The time allocation in post Kahoot quiz was increased from 10 seconds in the first quiz to 15 to 20 seconds due to consideration that external communication required more time in determining the answer. This is because in external communication the understood vocabularies were more numerous and complex even not only in the form of words but also in the form of expressions and groups of words or phrases. So that cadets were expected to be able to express utterances which were commonly used in external communication between ship to port authorities and with VTS (vessel traffic services). As an example of a communication between a ship and port authority is that when a ship is about to go berthing, communication will occur with the pilot station to ask for pilotage and directed to its pier. Phrases and not just short words were required as it was ruled and structured by Standard Maritime Communication Phrases. By referring to this, the communication was easily understood and structured. As the results of Kahoot quiz in the post-action phase, it led more cadet's enthusiasm to memorize vocabularies and terminologies in the form of words and structured expressions so that when they played with this quiz they would be 
ready with the expressions they should use when they are exactly aboard the ship. The results of the Kahoot post-action can be seen from the following statistics;

Tabel 4a. Post-Action Kahoot

\begin{tabular}{lrr}
\hline \multicolumn{2}{l}{ Statistics of Post Kahoot Result } & \\
\hline $\mathrm{N}$ & Valid & 21 \\
& Missing & 0 \\
Mean & & 9.7619 \\
Std. Deviation & & 1.72930 \\
Minimum & 7 \\
Maximum & 13 \\
\hline
\end{tabular}

Tabel 4b. Post-Action Kahoot

\begin{tabular}{rlrrrr}
\hline & Frequency & Percent & Valid Percent & Cumulative Percent \\
\hline Valid & 7.00 & 2 & 9.5 & 9.5 & 9.5 \\
& 8.00 & 4 & 19.0 & 19.0 & 28.6 \\
& 3.00 & 14.3 & 14.3 & 42.9 \\
10.00 & 5 & 23.8 & 23.8 & 66.7 \\
11.00 & 3 & 14.3 & 14.3 & 81.0 \\
12.00 & 3 & 14.3 & 14.3 & 95.2 \\
& 3.00 & 1 & 4.8 & 4.8 & 100.0 \\
& 21 & 100.0 & 100.0 & \\
\hline
\end{tabular}

It is known that out of the 21 cadets who took the Kahoot post-action quiz as an evaluation test increased their ability in answering the 15 questions. Compared from the pre Kahoot quiz there was increasing number of cadets who can answer more correct answer. Here, we can see the chart below.

Table 5. Tabulation of the Frequent Number of Correct Answers

\begin{tabular}{cll}
\hline No. & Section & Mean \\
\hline 1. & Pre-action Kahoot & 7.47 \\
2. & Post-action Kahoot & 9.76 \\
\hline
\end{tabular}

Frequent number of correct answers made by the cadets increased significantly from the Pre-action Kahoot quiz to the Post-action Kahoot. It is shown from the average correct number done by the cadets. The mean of correct answer in the second Kahoot quiz is higher than that of the first which increased from 7,47 to 9,76. It means cadet's mastery on terminologies which could be assumed to make them having better capability on their oral reproduction developed either.

Out of the 15 questions given, the average cadet who could answer correctly at least 10 questions were about 12 cadets or around $57.2 \%$. Moreover, there were three cadets who could answer 12 questions correctly or it was around $14.3 \%$. And there was one cadet with the most correct answers of 13 questions or about $4.8 \%$. In conclusion there were about 16 cadets or $76,19 \%$ that could answer more correct answer compared to that in the pre-action Kahoot. 


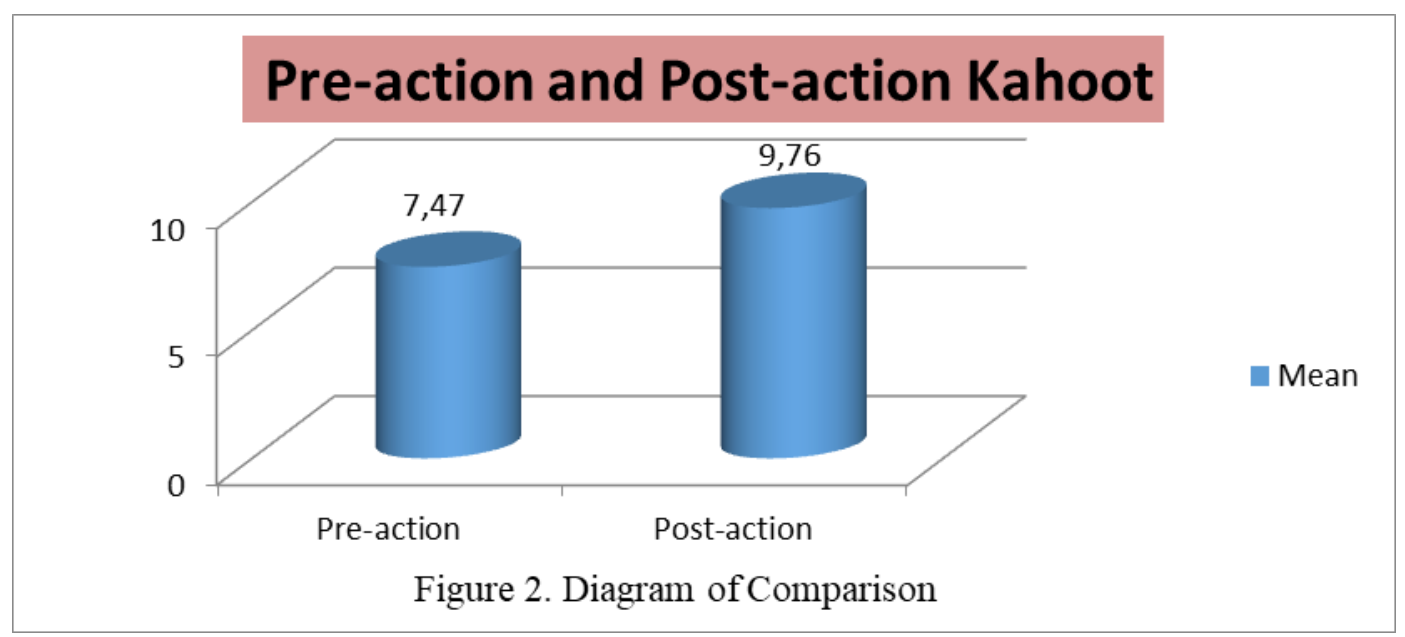

\section{Constraint of the quiz}

The use of Kahoot as online quiz did not always run smoothly. Based on the observation sheet, it was analyzed that there might be some constraints occured. One of the mostly occured obstruction it was due to the internet connection. At first, the lecturer could run the quiz smoothly because of the good internet bound using wifi facility at campus. However, once the cadet would response to the quiz the problem happened when they used their own internet data. If they had got sufficient quotas there would be no connection obstruction happened. On the other hand it was found that $23.81 \%$ or it was around 5 cadets out of 21 did not get enough quotas to run the quiz smoothly. Besides, another problem occured toward some cadets who used distinghuised internet provider. It was caused by the signal strengths. For several cadets who got strong signal, they can follow and response to the quiz immediately without any delay thus they did not miss any single question to answer. Fortunately, there were around 14 cadets out of 21 or it was about $66.67 \%$ that had got opportunities to answer all questions. The other $9,52 \%$ or it was around 2 cadets found difficulties in responding to the quiz due to the poor signal. As a result, prior the use of Kahoot quiz, the internet and data connection as technical support is compulsory to consider. Lecturer must ensure that Kahoot quiz could run smootly and there were no obstructions due to technical problems.

\section{CONCLUSION}

From the results of the two Kahoot quiz cycles, it could be seen that the Kahoot quiz turned out to have a significant influence in the vocabularies and terminologies mastery of Maritime English context and it supported the smoothness of cadet's oral reproduction. Regarding the involvement of Kahoot quiz as online gamification in Maritime English teaching, the cadets felt more enthusiastic and pleased to learn so that they themselves were better encouraged to learn more and more. This self-motivation brought a great learning desire and led to better understanding. Furthermore, in the recent era of industrial revolution 4.0, integrating online gamification learning in Foreign Language (EFL) learning with technology-based learning would present a good alternative teaching method for educators to attract cadet's interest and achieve cadet's target of learning while at the same time it prepares them to become qualified human resources in sophisticated digital era. 


\section{REFERENCES}

Arikunto, S. (2015). Penelitian tindakan kelas. Jakarta: Bumi Aksara

Cheng, C. H. \& Su, C.H. (2012). A game-based learning system for improving student's learning effectiveness in system analysis course. Procedia-Social and Behavioral Sciences, 31, 669-675. doi:10.1016/j.sbspro.2011.12.122

Denzin,N.K. \& Lincoln,Y.S. (2005). Participatory action research: Communicative action and the public sphere. Thousand Oaks: Sage Publication.

Esteves, M., Pereira,A., Veiga,N., Vasco,R., \& Veiga,A. (2018). The use of new learning technologies in higher education classroom: A case study. International Journal of Engineering Pedagogy, 8(2),115-127. Retrieved from https://onlinejournals.org/index.php/i-jep/article/view/8146

Farabi, M., Hassanvand,S., \& Gorjian, B. (2017). Using guided oral presentation in teaching English language learners' speaking skill. Journal of Applied Linguistics, 3(1),17-24. doi:10.5923/j.jall1.20170301.03

Florez, M.A. (1999). Improving adult English language learner's speaking skills. ERIC Digest. ERIC Document Reproduction. 4(3), 20-32. Retrieved from https://eric.ed.gov/?id=ED435204

Hadijah, Pratolo, B. W., \& Rondiyah. (2020). Interactive game "Kahoot!" as the media of students' vocabulary assessment. Journal on English as a Foreign Language, 10(1), 84-102. https://doi.org/10.23971/jefl.v10i1.1670

Haryanto,S. (2018). Kelebihan dan kekurangan E-learning berbasis schoology (studi PTK dalam pembejaran mata kuliah academic listening). Prosiding Seminar Nasional Geotik. Surakarta, P.106-110. Retrieved from http://hdl.handle.net/11617/9852

Hutchinson,T. \& Waters, A. (1987). English for specific purposes. Cambridge: Cambridge University Press.

International Maritime Organization. (2000). Standard marine communication phrase. Rijeka: IMO

Kemmis, S. \& Mc Taggart, R. (1988). The action research planner. Victoria: Deakin University Press.

Nunan, D. (2003). Practical English language teaching. New York: Mc Grow Hill Contemporary.

Nunan, D. (1999). Second language teaching and learning. Boston: Heinle \& Heinle.

Pratama,W. \& Sartini, S. (2019). Perguruan tinggi kemaritiman menghadapi revolusi industri 4.0. Majalah Ilmiah Bahari Jogja,Vol 17(2), 86-92. doi: 10.33489/mibj.v17i2

Saturno, M., Pertel, V.M., Deschamps, F., \& de F.R.Loures E. (2018). Proposal of an automation solutions architecture for industry 4.0. LogForum,14 (2), 185-195. Retrieved from https://www.logforum.net/pdf/14_2_4_18.pdf

Stanic, V., Hadjina, M., Fafandjel, N., \& Matulja, T. (2018). Toward shipbuilding 4.0-an industry 4.0 changing the face of the shipbuilding industry. Brodogradnja /shipbuilding/open access. Vol.69(3). doi: 10.21278/brod69307

St-Pierre, M-C. \& Béland, R. (2010). Reproduction of inflectional markers in Frenchspeaking children with reading impairment. Journal of Speech, Language and Hearing Research (JSLHR), vol. 53, p. 469-489. Retrieved from https://pubs.asha.org/doi/10.1044/1092-4388\%282009/07-0251\%29 
Vidhiasi, D.M. (2018). The use of Kahoot in teaching maritime English: A case study. Proceeding of the $1^{\text {st }}$ Cilacap National Conference on Maritime and Multidisciplinary Study. Cilacap. P.136-146. doi: 10.6084/m9.figshare.7988576

Wiggins, B.E. (2016). An overview and study on the use of games, simulations, and gamification in higher education. International Journal of Game-Based Learning. Vol. 6 (1), 18-29. doi: 10.4018/IJGBL.2016010102 